\title{
Fındık Tarımı Yapılan Toprakların Bazı Fiziksel ve Kimyasal Özellikleri ile Verimlilik Durumlarının Belirlenmesi
}

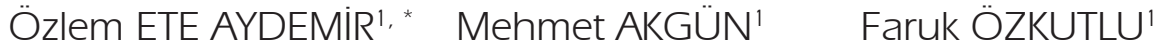 \\ 'Ordu Üniversitesi Ziraat Fakültesi Toprak Bilimi ve Bitki Besleme Bölümü, 52200, Altınordu/ Ordu
}

*Sorumlu yazar e-mail (Corresponding author e-mail): ozlemete87@gmail.com

Geliș tarihi (Received) : 13.07.2020

Kabul tarihi (Accepted): 19.10.2020

DOI: $10.21657 /$ topraksu.768642

\section{Öz}

Fındıkta yüksek verim ve kaliteli ürün alınmasının ön koșullarından birisi toprak ve yaprak analizlerine göre doğru gübrelemedir. Bu araștırma, Ordu Illi fındık tarımı yapılan bahçelerin verimlilik durumunu belirleyebilmek için 40 farklı bahçeden toprak örneği alınarak toprakların bazı fiziksel ve kimyasal analizleri yapılmasıyla verimlilik durumları belirlenmiștir. Toprakların bünye (tekstür), $\mathrm{pH}$ ve kireç durumları saptanmıș ve sınır değerlerle kıyaslanmıștır. Buna göre, toprakların pH düzeyleri hafif asitten hafif alkaliye arasında değiștiği ve genellikle az kireçli olduğu belirlenmiștir. Toprakların mineral besin elementleri arasından \%90'ında fosfor, \%62.5'inde kalsiyum, \%100'ünde magnezyum ve \%52.5'sinde ise çinko bakımından noksan olduğu saptanmıștır. Elde edilen sonuçlara göre fındık yetiștiriciliği yapılan bahçelerin özellikle besin elementleri bakımından yetersiz olduğu ortaya çıkmıștır. Fındıkta gübrelemede tek düze gübreleme yerine çok besinli gübrelerin kullanılmasıyla beslenme sorunu giderilebilir.

Anahtar Kelimeler: Ordu, Corylus avellana L, toprak verimliliği

\section{Determination of Some Physical and Chemical Properties and Fertility Capacity of Soils under Hazelnut Cultivation}

\begin{abstract}
One of the prerequisites for high yield and quality in hazelnut farming is accurate fertilization based on soil and leaf analysis. This study is carried out to determine fertility status of the soils under hazelnut cultivation in Ordu Province by testing physical and chemical properties of the soil samples taken from 40 hazelnut orchards. The texture, $\mathrm{pH}$ and lime status of the soils were determined and compared with the limit values. Accordingly, it was determined that the soils were generally low in lime and pH levels were changing from slightly acidic to slightly alkali. The comparison of mineral nutrition elements of the soils with the limit values revealed that $90 \%, 62.5 \%, 100 \%$ and $52.5 \%$ of the soils were deficient for phosphorous, calcium, magnesium and zinc, respectively. The results of the present study indicated that there was a nutritional problem in the soils under hazelnut cultivation. This nutritional problem can be solved using multi nutritional fertilizers in hazelnut cultivation.
\end{abstract}

Keywords: Ordu, Corylus avellana L, soil fertility

\section{Gíriș}

Dünya üzerinde toplamda 966.196 hektar'lık bir alanda fındık yetiștiriciliği yapııdığı açıklanmıștır (FAO, 2020). Türkiye bu alanın 728.381 hektar'lık kısmında findık yetiștirmektedir. Türkiye'de findık üretim miktarında yıldan yıla değișiklik olsa da dünya

fındık üretiminin yaklașık \%70-75'ini karșılayarak lider ülke konumundadır. Türkiye'de üretilen findığın \%31'lik kısmı 227.311 ha üretim alanı ile Ordu Ili bașı çekmektedir (TUiK, 2020). Ordu ili findık üretimi bakımından ilk sırada yer almasına karșın dekar 
bașına aldığı verim diğer illere kıyasla daha düșüktür. Fındıkta verim düșüklüğüne neden olan birçok faktör yer almaktadır. Bu faktörlerden bazıları olarak, kültürel (budama ve yabancı ot temizliği) uygulamaların yapılmaması, bahçelerin çok eğimli olması ve yanlıș gübreleme programlarının uygulanması sayılabilir. Bahsedilen kültürel uygulanmaların yapılması koșuluyla findıkta yüksek verim ve kaliteli ürün alınabilmesi için intiyaç duyulan bitki besin elementlerinin yeterli miktarda uygulanmasına bağlıdır. Bitki besin elementlerinin bitkiler tarafından sürekli olarak sömürülmesi ve yapılan bilinçsiz gübrelemeyletopraklarınverimlilikkapasitelerigünden güne azalmaktadır. Tarım alanlarındaki verimlilik durumlarının sürdürülebilmesi için bu alanların en iyi șekilde tanımlanması gerekir. Farklı yollarla topraktan eksilen bitki besin maddelerinin toprağa tekrardan geri kazandırıması zorunludur. Bundan dolayı bitkilerin intiyaç duydukları besin elementleri ve beslenme durumlarının belirlenmesi için toprak analizi sıkça bașvurulan yöntemlerden birisidir. Orta ve Doğu Karadeniz Bölgesinde findık yetiștirilen bazı alanlarda toprakların verimlilik düzeyinin tespitine yönelik araștırmalar yer almaktadır. Bu araștırmaların birçoğunda, bölgede toprakta ve yapraklarda besin elementlerinin mevcut durumunu gösteren çalıșmalarda (Aydın ve vd., 2000; Tarakçıoğlu, 2003; Adiloğlu ve Adiloğlu 2005; Șendemirci ve Korkmaz 2008; Özyazıcı vd., 2016; Esençayı, 2019) birçok mineral elementlerin eksikliğine/fazlalığına dikkat çekilmiștir. Söz konusu araștırmaların sonuçlarına göre, topraklarda en yaygın besin elementi noksanlıkları arasında fosfor (P), potasyum (K) ve çinko (Zn) görüldüğü açıklanmıștır. Yapılan araștırmaların çoğunluğunda Doğu Karadeniz Bölgesinde $\mathrm{pH}$ değerlerinin geniș bir aralıkta yer aldığı ve toprakların çok büyük bir bölümünün az kireçli ve organik madde yönünden yüksek durumda yer aldığı saptanmıștır. Orta ve Doğu Karadeniz Bölgesinde ylllık yağıș miktarının 900 mm ile 1600 mm arasında olması nedeniyle önemli oranda makro ve mikro elementlerin yıkanarak topraktan uzaklașmasına bağlı olarak eksiklikler görülebilmektedir. Bu nedenle, bölgede toprakların fiziksel ve kimyasal özelliklerinin sıklıkla belirlenmesine intiyac duyulmaktadır. Bu araștırma, Ordu ili findık tarımı yapılan bazı bahçelerden alınan toprakların verimlilik durumlarının değerlendirilmesi amaçlanmıștır.

\section{MATERYAL VE YÖNTEM}

Araștırmanın materyalini, Ordu ilinin fındık tarımı yapılan farklı lokasyonlarından alınan

Çizelge 1. Toprak örneklerinin alındığı koordinatlar

Table 1. Coordinates from which soil samples are taken

\begin{tabular}{|c|c|c|c|c|c|c|c|}
\hline \multirow{2}{*}{$\begin{array}{l}\text { Örnek } \\
\text { No }\end{array}$} & \multicolumn{3}{|c|}{ Koordinatlar } & \multirow{2}{*}{$\begin{array}{c}\text { Örnek } \\
\text { No }\end{array}$} & \multicolumn{3}{|c|}{ Koordinatlar } \\
\hline & X-GPS & Y-GPS & Rakım & & X-GPS & Y-GPS & Rakım \\
\hline 1 & 417191 & 4536413 & 50 & 21 & 405731 & 4532590 & 81 \\
\hline 2 & 417191 & 4536437 & 51 & 22 & 405814 & 4532831 & 65 \\
\hline 3 & 417259 & 4536409 & 49 & 23 & 405810 & 4532827 & 50 \\
\hline 4 & 417071 & 4536398 & 48 & 24 & 405892 & 4532152 & 48 \\
\hline 5 & 424623 & 4534702 & 35 & 25 & 390973 & 4522443 & 606 \\
\hline 6 & 424496 & 4534773 & 35 & 26 & 391012 & 4522403 & 600 \\
\hline 7 & 424623 & 4534697 & 35 & 27 & 391010 & 4522401 & 611 \\
\hline 8 & 424152 & 4534839 & 35 & 28 & 391156 & 4522186 & 551 \\
\hline 9 & 424834 & 4534538 & 35 & 29 & 390850 & 4521980 & 563 \\
\hline 10 & 409655 & 4533932 & 65 & 30 & 390848 & 4521978 & 554 \\
\hline 11 & 409442 & 4534021 & 64 & 31 & 390808 & 4522170 & 614 \\
\hline 12 & 409219 & 4534071 & 84 & 32 & 390699 & 4521561 & 594 \\
\hline 13 & 405648 & 4528560 & 274 & 33 & 390847 & 4521171 & 521 \\
\hline 14 & 405644 & 4528556 & 88 & 34 & 390843 & 4521169 & 511 \\
\hline 15 & 406018 & 4534884 & 89 & 35 & 391842 & 4521831 & 503 \\
\hline 16 & 406008 & 4534834 & 87 & 36 & 358905 & 4548141 & 29 \\
\hline 17 & 406008 & 4534834 & 84 & 37 & 358905 & 4548141 & 29 \\
\hline 18 & 405843 & 4535023 & 120 & 38 & 359257 & 4552682 & 16 \\
\hline 19 & 404915 & 4534974 & 161 & 39 & 357083 & 4552074 & 72 \\
\hline 20 & 404822 & 4535539 & 97 & 40 & 356990 & 4551985 & 79 \\
\hline
\end{tabular}


toplam 40 adet toprak örneği olușturmaktadır. Örnekleme noktalarına ait GPS kayıtları çizelge 1'de verilmiștir. Toprak örnekleri genel kurallara uygun olarak (Jackson, 1958), 0-30 cm derinlikten paslanmaz çelik kürek ile fındık ocaklarının yaprak izdüșümlerinden alınmıștır. Alınan toprak örnekleri laboratuvar koșullarında kurutma tezgâhlarına serilerek, taș, bitki gibi farklı parçacıklar ayıklanmıș ve havada kurumaya bırakılmıștır. Kuruyan topraklar tahta tokmaklarla dövülerek 2 mm'lik çelik elekten geçirilip analizlere hazır hale getirilmiștir.

\section{Toprak Örneklerinde Yapılan Analizler}

Toprak reaksiyonu 1:2.5 toprak / su karıșımında cam elektrotlu $\mathrm{pH}$-metre ile (Jackson, 1958), elektriksel iletkenlik değeri 1:2.5 oranında saf su ile sulandırımıș toprak örneklerinde EC metre ile (Richards, 1954), toprakta tekstür analizi Bouyoucos (1951)'e göre, toprakta kireç Hızalan ve Ünal (1966) tarafından açıklandığı șekilde Scheibler kalsimetresiyle, organik madde Walkley-Black yaș yakma yöntemine göre (Jackson 1962), toplam N Bremner (1965). bitkiye yarayıșlı P analizi Olsen vd. (1 954)'e göre, ekstrakte edilebilir K, Ca ve Mg amonyum asetat yöntemiyle Pratt (1965)'e göre bitkiye yarayıșlı Fe, Cu, Zn, Mn DTPA yöntemi Lindsay ve Norvell (1978) e göre, alınabilir B ise Wolf (1971)'e göre belirlenmiștir.

\section{BULGULAR VE TARTISMA}

Ordu ilinin 40 farkı fındık bahçesinden alınan topraklarının tekstür, pH, EC (tuzluluk), kireç ve organik madde düzeylerine ilișkin veriler Çizelge 2'de sunulmuștur.

Toprakların tekstür sınıfları değișkenlik göstermekle birlikte toplam örneklerin \%40'nın killi olduğu bunu takiben \%25'inin killi tın ve \%15'inin tınlı (Bouyoucos, 1951) olduğu belirlenmiștir (Șekil 1). Toprak örneklerinin pH'ları 5.2-7.9 arasında olup orta asitten hafif alkali karaktere kadar değiștiği belirlenmiștir. Toprak örnekleri Richards (1954) tarafından belirlenen $\mathrm{pH}$ değerlerine göre sınıflandırıldığında; toprak örneklerinin \%10'u orta asit reaksiyonlu, $\% 22.5^{\prime}$ nötr ve \%62.5'i de hafif asit reaksiyonlu olduğu belirlenmiștir (Șekil 2). Araștırmaya konu olan toprakların tamamının tuzsuz (Maas, 1986) olduğu tespit edilmiștir (Șekil 3). Toprakların kireç kapsamları \%0.2'den \%13.9'a kadar değiștiği ve ortalama \% 1.1 seviyesinde olduğu belirlenmiștir
(Çizelge 2). Toprak örneklerinin Hızalan ve Ünal, (1966) göre sınıflandırılığında örneklerin \%5'nin "kirecli", \%7.5'nun "orta kirecli ve \%87.5'nin "az kireçli" olduğu belirlenmiștir (Șekil 4). Toprakların organik madde düzeyleri \%1.4'den \%5.1'a değiștiği ve ortalama \%2.9 seviyesinde olduğu belirlenmiștir (Cizelge 2). Toprakların organik maddesi sınır değerlerle kıyaslandığında toplam örneklerin \%20'si "az", \%32.5'u "orta" ve \%45'inin de "iyi" (Jackson 1958) olarak sınıflandırıldığı saptanmıștır (Șekil 5).

Doğu Karadeniz Bölgesi yıllık 900-1600 mm arasında yağıș alması nedeniyle genellikle bölge topraklarının kuvvetli asit karakterde olduğu düșünülmektedir. Oysa yapılan araștırmada toplam toprak örneklerinin \%62.5'inin hafif asit karakterde olduğu bulunmuștur. Fındık yetiștiriciliğinde hafif asit reaksiyonlu toprakların daha ideal olduğu bildirilmiștir ( Genç ve Sarıhan, 1976; Özbek, 1981). Toprakların kireç içerikleri düșük ve tamamının tuzsuz olduğu belirlenmiștir. Konu ile ilgili yapılan benzer çalıșmalarda Tarakçığlu vd. (2003), Ordu yöresi fındık bahçelerinden aldığı 65 adet toprak örneğinin \% 40 hafif asit ve \% 20'sinin nötr reaksiyona sahip, $\% 77$ 'sinin az kireçli, topraklar genel olarak killi ve killi tınlı bünyeli ve organik madde bakımından yeterli olduğunu tespit etmișlerdir. Özkutlu vd. (2016) ise fındık bahçesi topraklarının \%39 ve \%26'sının sırasıyla hafif ve orta asitli, \% 96'sının az kireçli olduğunu, organik maddece \%11 noksanlık olduğu bildirmișlerdir. Özyacı vd. (2016) tarafından Orta ve Doğu Karadeniz Bölgesi tarım topraklarının temel verimlilik düzeylerini belirlemek amacıyla 3400 toprak örneği alarak yaptıkları çalıșma sonucunda tarım arazilerinin \%75.30'nun tınlı topraklar olup, $\mathrm{pH}$ değerlerinin 4.5 ile 8.5 arasında değișkenlik gösterdiğini, toprakların büyük çoğunluğunun organik madde bakımından orta düzeyde, \%61.15'inin az kireçli ve toprakların tamamının tuzsuz olduğunu saptamıștır.

Araștırmada kullanılan toprakların fosfor $(\mathrm{P})$, potasyum (K), kalsiyum (Ca) ve magnezyum (Mg) konsantrasyonları belirlenmiștir (Çizelge 3). Toprakların P konsantrasyonları $0.5 \mathrm{mg} \mathrm{kg}^{-1}$ ile $50.3 \mathrm{mg} \mathrm{kg}^{-1}$ arasında değiștiği, ortalama $4.3 \mathrm{mg}$ $\mathrm{kg}^{-1}$ düzeyinde olduğu belirlenmiștir. Toprakların K konsantrasyonunun $29 \mathrm{mg} \mathrm{kg}^{-1}$ ile $361 \mathrm{mg} \mathrm{kg}^{-1}$ arasında değiștiği ortalama $124 \mathrm{mg} \mathrm{kg}^{-1}$ olduğu tespit edilmiștir. En düșük Ca konsantrasyonunun 
Çizelge 2. Araștırmada kullanılan toprakların tekstür, $\mathrm{pH}$, kireç $\left(\mathrm{CaCO}_{3}\right)$, elektiriksel iletkenlik (EC) ve organik madde kapsamları

Table 2. Texture, $\mathrm{pH}$, lime $\left(\mathrm{CaCO}_{3}\right)$, electrical conductivity $(\mathrm{EC})$ and organic matter content of soils used in the research

\begin{tabular}{|c|c|c|c|c|c|}
\hline Örnek & & & & & \\
\hline No & Tekstür & $\mathrm{pH}$ & $\mathrm{EC}, \mathrm{dS} / \mathrm{m}$ & Kireç, \% & $\mathrm{OM}, \%$ \\
\hline 1 & Killi & 6.2 & 0.03 & 0.67 & 1.7 \\
\hline 2 & Killi Tın & 6.8 & 0.05 & 0.46 & 1.6 \\
\hline 3 & Tin & 5.5 & 0.02 & 0.51 & 1.4 \\
\hline 4 & Tın & 6.5 & 0.03 & 0.42 & 1.7 \\
\hline 5 & Killi Tın & 6.0 & 0.03 & 0.46 & 1.7 \\
\hline 6 & Killi & 6.2 & 0.02 & 0.38 & 1.7 \\
\hline 7 & Killi Tın & 5.2 & 0.03 & 0.46 & 3.1 \\
\hline 8 & Killi & 5.9 & 0.03 & 0.51 & 3.8 \\
\hline 9 & Killi Tın & 6.2 & 0.03 & 0.21 & 3.2 \\
\hline 10 & Killi Tın & 7.6 & 0.10 & 0.84 & 3.9 \\
\hline 11 & Killi & 7.3 & 0.13 & 6.74 & 3.0 \\
\hline 12 & Killi & 6.5 & 0.05 & 0.84 & 3.8 \\
\hline 13 & Kumlu Killi Tın & 6.3 & 0.03 & 0.55 & 3.3 \\
\hline 14 & Killi & 6.2 & 0.13 & 0.51 & 3.7 \\
\hline 15 & Killi & 5.8 & 0.03 & 0.29 & 3.3 \\
\hline 16 & Siltli Killi Tın & 6.1 & 0.05 & 0.51 & 3.3 \\
\hline 17 & Kumlu Kil & 5.9 & 0.04 & 0.13 & 4.0 \\
\hline 18 & Killi & 5.4 & 0.04 & 0.21 & 3.8 \\
\hline 19 & Killi & 5.5 & 0.05 & 0.25 & 3.0 \\
\hline 20 & Killi & 6.3 & 0.02 & 0.21 & 3.8 \\
\hline 21 & Killi & 6.8 & 0.16 & 2.99 & 2.2 \\
\hline 22 & Killi & 6.3 & 0.04 & 0.13 & 2.9 \\
\hline 23 & Killi & 6.1 & 0.07 & 0.21 & 2.8 \\
\hline 24 & Killi & 6.3 & 0.04 & 0.29 & 3.0 \\
\hline 25 & Killi & 6.4 & 0.05 & 0.17 & 2.5 \\
\hline 26 & Killi Tın & 6.6 & 0.03 & 0.08 & 3.4 \\
\hline 27 & Tın & 6.3 & 0.04 & 0.04 & 3.6 \\
\hline 28 & Kumlu Killi Tın & 5.7 & 0.04 & 0.08 & 3.3 \\
\hline 29 & Tin & 6.6 & 0.04 & 0.08 & 2.7 \\
\hline 30 & Kumlu Killi Tın & 6.6 & 0.07 & 0.13 & 3.3 \\
\hline 31 & Tin & 6.3 & 0.04 & 0.02 & 2.2 \\
\hline 32 & Kumlu Killi Tın & 6.5 & 0.06 & 2.28 & 2.3 \\
\hline 33 & Kumlu Killi Tın & 6.6 & 0.03 & 0.46 & 1.6 \\
\hline 34 & Kumlu Tın & 6.4 & 0.03 & 0.63 & 1.4 \\
\hline 35 & Killi Tın & 6.1 & 0.04 & 0.38 & 2.4 \\
\hline 36 & Killi Tın & 6.4 & 0.04 & 0.25 & 2.8 \\
\hline 37 & Killi Tın & 6.4 & 0.04 & 0.25 & 2.8 \\
\hline 38 & Killi Tın & 7.9 & 0.16 & 13.9 & 3.4 \\
\hline 39 & Killi & 6.7 & 0.14 & 0.42 & 5.1 \\
\hline 40 & Tın & 6.9 & 0.20 & 5.22 & 2.5 \\
\hline En Düșük & & 5.2 & 0.02 & 0.2 & 1.4 \\
\hline En Yüksek & & 7.9 & 0.20 & 13.9 & 5.1 \\
\hline Ortalama & & 6.3 & 0.06 & 1.1 & 2.9 \\
\hline
\end{tabular}

26 


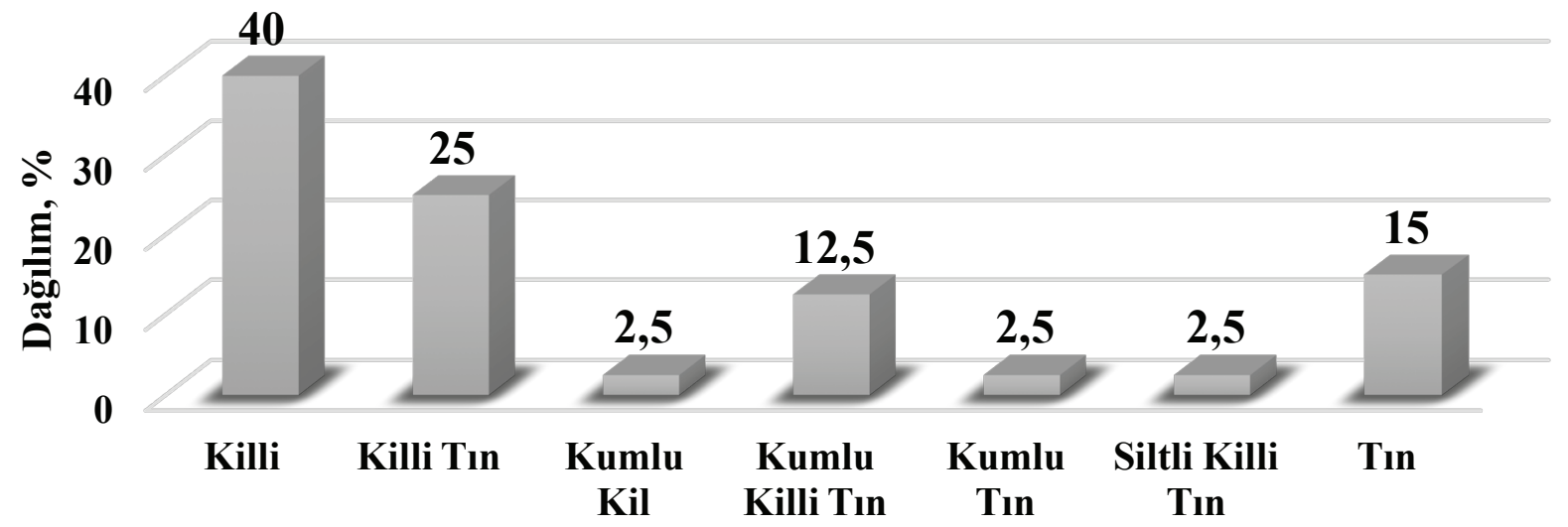

Șekil 1. Ordu İli fındık tarımı yapılan toprakların tekstür sınıflarına göre dağıımları, \%

Figure 1. Distribution of Ordu hazelnut cultivated soils according to texture classes, \%

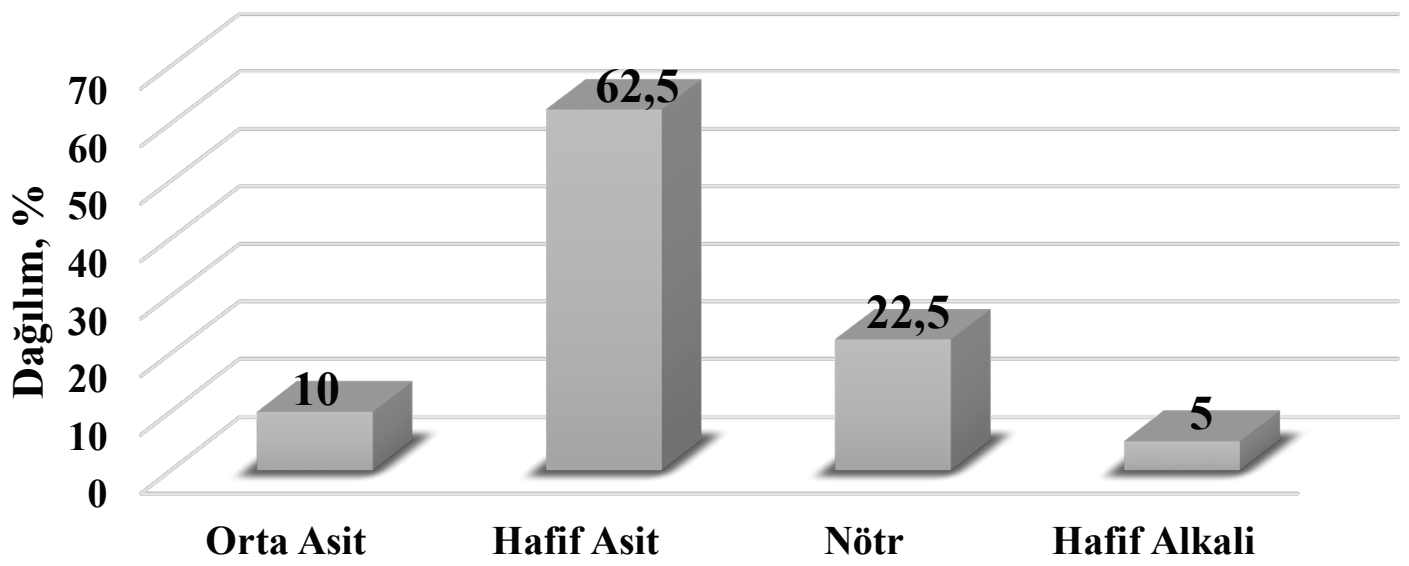

Sekil 2. Ordu Illi fındık tarımı yapılan toprakların pH değerlerine göre dağılımları, \% Figure 2. Distribution of soils cultivated in Ordu according to $\mathrm{pH}$ values, \%

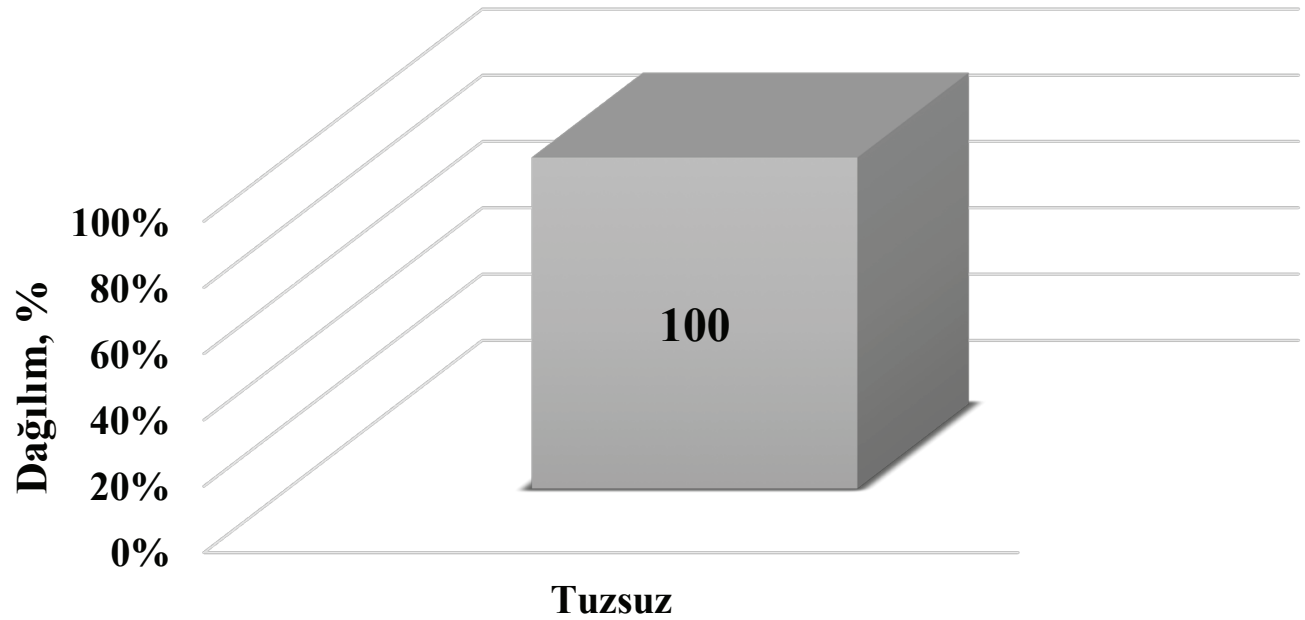

Șekil 3. Ordu Illi fındık tarımı yapılan toprakların EC kapsamlarına göre dağıımları, \%

Figure 3. Distribution of soils cultivated in Ordu according to EC content, \% 


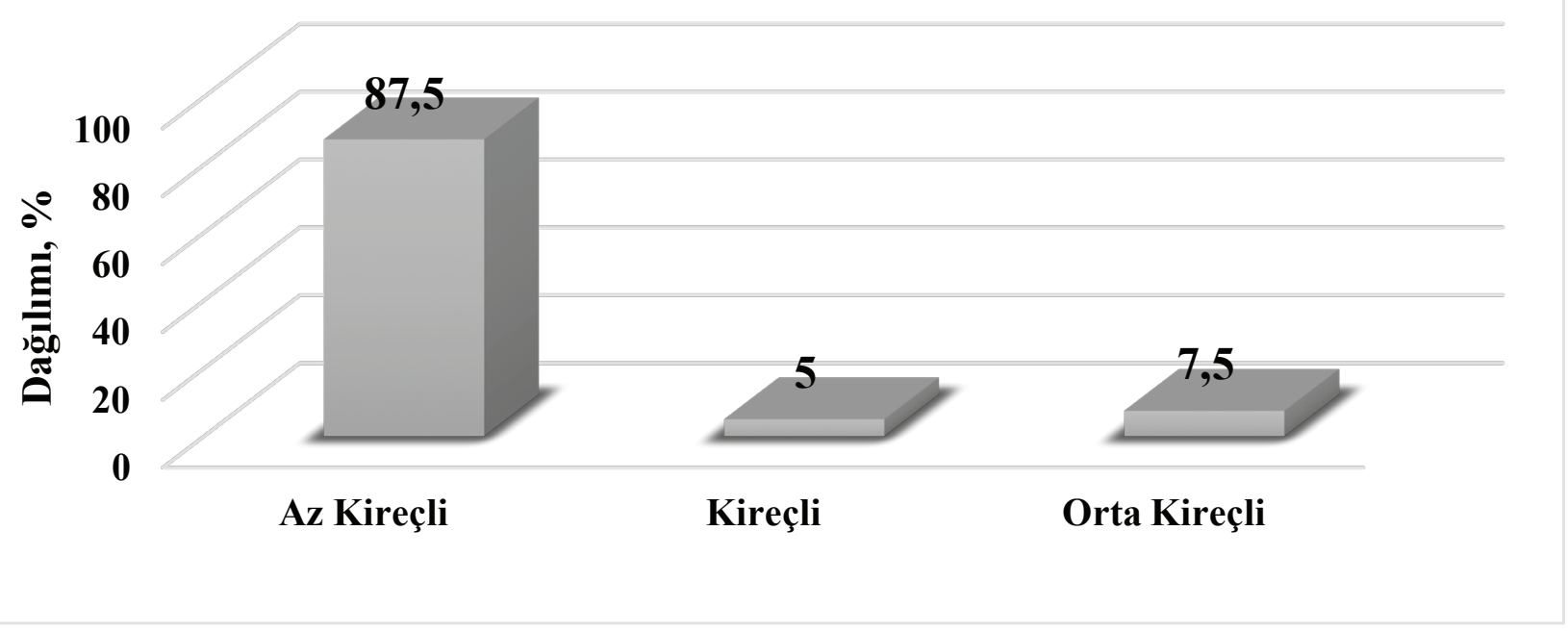

Șekil 4. Ordu İli fındık tarımı yapılan toprakların kireç kapsamlarına göre dağııımları, \%

Figure 4. Distribution of hazelnut cultivated soils in Ordu according to the lime content,

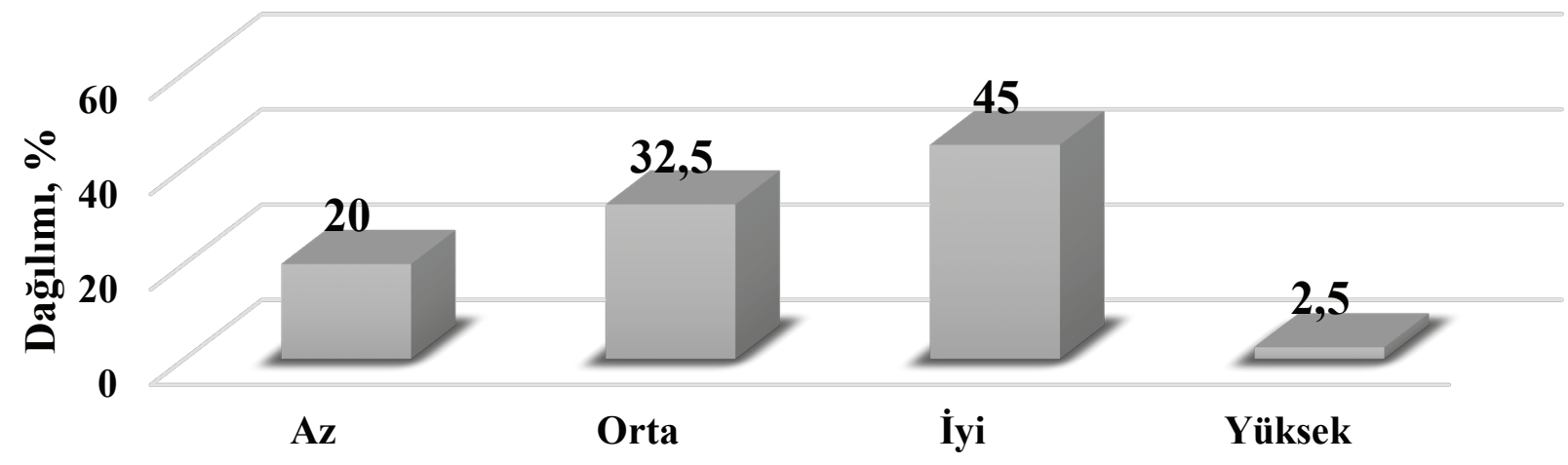

Șekil 5. Ordu İli fındık tarımı yapılan toprakların organik madde dağılımları, \%

Figure 5. Distribution of hazelnut cultivated soils in Ordu according to the organic matter content, \%

$136 \mathrm{mg} \mathrm{kg}^{-1}$ en yüksek Ca konsantrasyonunun ise $679 \mathrm{mg} \mathrm{kg}^{-1}$ olduğu belirlenmiștir. $\mathrm{Mg}$ konsantrasyonunun $15 \mathrm{mg} \mathrm{kg}^{-1}$ ile $42 \mathrm{mg} \mathrm{kg}^{-1}$ arasında farklıık gösterdiği ortalama olaraksa 32 mg kg-1 olduğu saptanmıștır (Çizelge 3).

Doğu Karadeniz Bölgesi yıllık 900-1600 mm arasında yağıș alması nedeniyle genellikle bölge topraklarının kuvvetli asit karakterde olduğu düșünülmektedir. Oysa yapılan araștırmada toplam toprak örneklerinin \%62.5'inin hafif asit karakterde olduğu bulunmuștur. Fındık yetiștiriciliğinde hafif asit reaksiyonlu toprakların daha ideal olduğu bildirilmiștir ( Genç ve Sarıhan, 1976; Özbek, 1981). Toprakların kireç içerikleri düșük ve tamamının tuzsuz olduğu belirlenmiștir. Konu ile ilgili yapılan benzer çalıșmalarda Tarakçıŏlu vd. (2003), Ordu yöresi fındık bahçelerinden aldığı 65 adet toprak örneğinin \% 
40 hafif asit ve \% 20'sinin nötr reaksiyona sahip, $\% 77$ 'sinin az kireçli, topraklar genel olarak killi ve killi tınlı bünyeli ve organik madde bakımından yeterli olduğunu tespit etmișlerdir. Özkutlu vd. (2016) ise fındık bahçesi topraklarının \%39 ve \%26'sının sırasıyla hafif ve orta asitli, \%96'sının az kireçli olduğunu, organik maddece \%11 noksanlık olduğu bildirmișlerdir. Özyacı vd. (2016) tarafından Orta ve Doğu Karadeniz Bölgesi tarım topraklarının temel verimlilik düzeylerini belirlemek amacıyla 3400 toprak örneği alarak yaptıkları çalıșma sonucunda tarım arazilerinin \%75.30'nun tınlı topraklar olup, $\mathrm{pH}$ değerlerinin 4.5 ile 8.5 arasında değișkenlik gösterdiğini, toprakların büyük çoğunluğunun organik madde bakımından orta düzeyde, \%61.15'inin az kireçli ve toprakların tamamının tuzsuz olduğunu saptamıștır.

Araștırmada kullanılan toprakların fosfor (P), potasyum (K), kalsiyum (Ca) ve magnezyum (Mg) konsantrasyonları belirlenmiștir (Çizelge 3). Toprakların P konsantrasyonları $0.5 \mathrm{mg} \mathrm{kg}^{-1}$ ile $50.3 \mathrm{mg} \mathrm{kg}^{-1}$ arasında değiștiği, ortalama $4.3 \mathrm{mg}$ $\mathrm{kg}^{-1}$ düzeyinde olduğu belirlenmiștir. Toprakların K konsantrasyonunun $29 \mathrm{mg} \mathrm{kg}^{-1}$ ile $361 \mathrm{mg} \mathrm{kg}^{-1}$ arasında değiștiği ortalama 124 mg kg-1 olduğu tespit edilmiștir. En düșük Ca konsantrasyonunun $136 \mathrm{mg} \mathrm{kg}^{-1}$ en yüksek Ca konsantrasyonunun ise $679 \mathrm{mg} \mathrm{kg}^{-1}$ olduğu belirlenmiștir. Mg konsantrasyonunun $15 \mathrm{mg} \mathrm{kg}^{-1}$ ile $42 \mathrm{mg} \mathrm{kg}^{-1}$ arasında farklıık gösterdiği ortalama olaraksa 32 mg kg-1 olduğu saptanmıștır (Çizelge 3).

Elde edilen bulgular incelendiğinde, toprakların \%90'nında yarayıșlı fosfor konsantrasyonu çok az olduğu tespit edilmiștir. Toprakların potasyum (K) konsantrasyonları FAO (1990) tarafından belirtilen sınır değerleri ile kıyaslandığında \%12.5 "çok az" ve \%30'u "az" olarak sınıflandırılmıș ve toprakların \%55'inde ise yeterli olduğu tespit edilmiștir. Toprakların değișebilir kalsiyum (Ca) miktarı \%62.5 ile "çok az" ve \%37.5'i "az" olarak sınıflandırılmıștır. Toprakıarın \% 100 'nün değișebilir Mg bakımından az olduğu belirlenmiștir (Çizelge 4).

Tarımsal olarak kaliteli ürün ve yüksek verimin alınabilmesi, bitki besin elementlerinin toprakta bulunma miktarına ve aynı zamanda bu elementlerin toprakta dengeli oranlarda bulunmasıyla mümkün olmaktadır. Kacar ve Katkat (2007), bitki bünyesinde immobil olan
Ca ve Mg gibi besin elementlerinin bașta asit tepkimeli topraklarda olmak üzere yeterli düzeyde alınamaması nedeniyle bu elementlerin noksanlığının belirgin șekilde ortaya çıkabileceği ve verimin olmușuz etkileneceğini bildirmișlerdir. Ordu ilinde yapılan çalıșmalarda benzer bulgular elde edilmiștir. Örneğin; Tarakçıoğlu ve ark (2003) Orduda yaptıkları çalıșmada yöre topraklarının yaklașık \%49.2'sinin P, \%69.2'sinin K, \%38.5'inin Ca bakımından orta ve düșük olduğunu tespit etmișlerdir. Özkutlu ve ark (2019) Ordu da yaptıkları bir çalıșmada 130 toprak örneğinin yaklașık \%57'si P bakımından noksan, \%43'nün ise orta düzeyde olduğunu, toprakların \% 27'sinin K konsantrasyonu "az" olarak bulunurken, \%64'ünün yeterli olduğunu tespit etmișlerdir. Orta ve Doğu Karadeniz Bölgesi tarım topraklarının temel verimlilik düzeylerini belirlemek amacıyla farklı noktalarda toplanan 3400 toprak örneğinin değerlendirmesi sonucunda toprakların \%58.83'ünde fosfor noksanlığını tespit etmiș ve ekstrakte edilebilir potasyumun yönünden de toprakların \%42.68'inin yeterli olduğunu açıklamıștır (Özyacı vd., 2016).

Toprakların bitkiye yarayıșlı Zn, Fe, Mn, Cu ve B konsantrasyonları çizelge 5'de verilmiștir. Toprakların Zn konsantrasyonu $0.1 \mathrm{mg} \mathrm{kg}^{-1}$ ile $2.3 \mathrm{mg} \mathrm{kg}^{-1}$ arasında değiștiği, ortalama değerin $0.8 \mathrm{mg} \mathrm{kg}^{-1}$ olduğu belirlenmiștir. Ortalama Fe, $\mathrm{Mn}$ ve Cu konsantrasyonları sırasıyla 45, 20 ve $1.3 \mathrm{mg} \mathrm{kg}^{-1}$ olarak tespit edilmiștir. Toprakların en düșük B konsantrasyonu $0.4 \mathrm{mg} \mathrm{kg}^{-1}$ olarak belirlenirken en yüksek B konsantrasyonu $2.7 \mathrm{mg} \mathrm{kg}^{-1}$ olarak belirlenmiș ortalama B konsantrasyonunun ise $1.1 \mathrm{mg} \mathrm{kg}^{-1}$ olduğu bulunmuștur.

Topraklarda mikro element konsantrasyonları sınır değerleri ile kıyaslandığında alınan toprak örneklerinin \%52.5'i çinko yönünden yetersiz olduğu tespit edilmiștir. Toprakların \%100'ünün Fe bakımından yeterli olduğu, \%95'inin Mn ve \%55'inin de Cu bakımından fazla olduğu tespit edilmiștir (Çizelge 6). Fındık yetiștiriciliğinin yoğun olduğu Ordu illinde genellikle azot ağırlıklı bir gübrelemenin yapıldığı bilinmektedir. Yapılan araștırmada, hem makro hem de mikro elementlerin intiyaç olduğu saptanmıștır. Özellikle Zn ve B gibi elementlerin noksanlığı Ordu ilinde bilinmemektedir. Ceșitli araștırmalarla toprakların Zn konsantrasyonlarını belirleme çalıșmaları 
Çizelge 3. Araștırmada kullanılan toprakların fosfor, potasyum, kalsiyum ve magnezyum konsantrasyonları

Table 3. TPhosphorus, potassium, calcium and magnesium concentrations of soils used in research

\begin{tabular}{|c|c|c|c|c|}
\hline \multicolumn{5}{|l|}{ Örnek } \\
\hline No & $\mathrm{P}, \mathrm{mg} / \mathrm{kg}$ & $\mathrm{K}, \mathrm{mg} / \mathrm{kg}$ & $\mathrm{Ca}, \mathrm{mg} / \mathrm{kg}$ & $\mathrm{Mg}, \mathrm{mg} / \mathrm{kg}$ \\
\hline 1 & 1.6 & 60 & 323 & 38 \\
\hline 2 & 0.8 & 41 & 382 & 37 \\
\hline 3 & 1.2 & 50 & 235 & 33 \\
\hline 4 & 0.9 & 50 & 337 & 36 \\
\hline 5 & 1.5 & 141 & 257 & 38 \\
\hline 6 & 0.6 & 136 & 239 & 38 \\
\hline 7 & 2.6 & 213 & 185 & 38 \\
\hline 8 & 0.7 & 136 & 228 & 35 \\
\hline 9 & 0.7 & 211 & 393 & 39 \\
\hline 10 & 1.1 & 182 & 614 & 20 \\
\hline 11 & 0.6 & 158 & 586 & 16 \\
\hline 12 & 2.4 & 115 & 654 & 27 \\
\hline 13 & 12.7 & 157 & 679 & 38 \\
\hline 14 & 2.5 & 361 & 432 & 33 \\
\hline 15 & 0.8 & 188 & 269 & 36 \\
\hline 16 & 1.7 & 211 & 220 & 38 \\
\hline 17 & 1.2 & 114 & 220 & 33 \\
\hline 18 & 1.1 & 156 & 184 & 32 \\
\hline 19 & 1.2 & 250 & 288 & 35 \\
\hline 20 & 1.9 & 57 & 212 & 31 \\
\hline 21 & 2.3 & 94 & 396 & 28 \\
\hline 22 & 1.1 & 93 & 324 & 34 \\
\hline 23 & 0.9 & 154 & 249 & 30 \\
\hline 24 & 2.3 & 108 & 245 & 30 \\
\hline 25 & 1.8 & 101 & 136 & 28 \\
\hline 26 & 0.9 & 65 & 282 & 36 \\
\hline 27 & 3.3 & 132 & 382 & 37 \\
\hline 28 & 3.6 & 118 & 293 & 35 \\
\hline 29 & 0.5 & 58 & 264 & 33 \\
\hline 30 & 6.6 & 62 & 506 & 42 \\
\hline 31 & 1.2 & 107 & 316 & 37 \\
\hline 32 & 19.2 & 155 & 566 & 33 \\
\hline 33 & 4.8 & 77 & 642 & 37 \\
\hline 34 & 20.7 & 58 & 582 & 33 \\
\hline 35 & 50.3 & 94 & 254 & 31 \\
\hline 36 & 1.5 & 29 & 301 & 31 \\
\hline 38 & 0.8 & 200 & 598 & 22 \\
\hline 39 & 4.5 & 75 & 331 & 18 \\
\hline 40 & 3.4 & 83 & 433 & 15 \\
\hline En Düșük & 0.5 & 29.0 & 136.0 & 15.0 \\
\hline En Yüksek & 50.3 & 361.0 & 679.0 & 42.0 \\
\hline Ortalama & 4.3 & 124.0 & 360.0 & 32.0 \\
\hline
\end{tabular}

$30 \mid$ 
Çizelge 4. Araștırmada kullanılan toprakların fosfor, potasyum, kalsiyum ve magnezyum analiz sonuçlarının durumu ve dağılımı Table 4. Condition and distribution of phosphorus, potassium, calcium and magnesium analysis results of soils used in the research

\begin{tabular}{|c|c|c|c|c|}
\hline Makro Element & $\begin{array}{c}\text { Sınır Değeri } \\
\text { ppm }\end{array}$ & Değerlendirme & $\begin{array}{c}\text { Toplam } \\
\text { Örnek Sayısı }\end{array}$ & $\begin{array}{l}\text { Dağılımı } \\
\% \\
\end{array}$ \\
\hline \multirow{5}{*}{$\begin{array}{c}P \\
\text { (Yurtsever, 1984) }\end{array}$} & $0-5$ & Çok az & 36 & 90 \\
\hline & $5-10$ & $A z$ & 0 & 0 \\
\hline & $10-15$ & Orta & 1 & 2.50 \\
\hline & $15-20$ & Yüksek & 1 & 2.50 \\
\hline & $>20$ & Çok Yüksek & 2 & 5.00 \\
\hline \multirow{5}{*}{$\begin{array}{c}\mathrm{K} \\
(\mathrm{FAO}, 1990)\end{array}$} & $<50$ & Çok az & 5 & 12.50 \\
\hline & 50-100 & $A z$ & 12 & 30.00 \\
\hline & $100-300$ & Yeterli & 22 & 55.00 \\
\hline & $300-1000$ & Fazla & 1 & 2.50 \\
\hline & $>1000$ & Çok Fazla & 0 & 0.00 \\
\hline \multirow{5}{*}{$\begin{array}{c}\text { Ca } \\
(\mathrm{FAO}, 1990)\end{array}$} & $<380$ & Çok az & 25 & 62.50 \\
\hline & 380-1150 & $A z$ & 15 & 37.50 \\
\hline & $1150-3500$ & Yeterli & 0 & 0.00 \\
\hline & $3500-10000$ & Fazla & 0 & 0.00 \\
\hline & $>10000$ & Çok fazla & 0 & 0.00 \\
\hline \multirow{5}{*}{$\begin{array}{c}\mathrm{Mg} \\
(\mathrm{FAO}, 1990)\end{array}$} & $<50$ & Çok az & 40 & 100.00 \\
\hline & $50-160$ & $A z$ & 0 & 0.00 \\
\hline & $160-480$ & Yeterli & 0 & 0.00 \\
\hline & $480-1500$ & Fazla & 0 & 0.00 \\
\hline & $>1500$ & Çok fazla & 0 & 0.00 \\
\hline
\end{tabular}

Çizelge 6. Araștırmada kullanılan toprakların çinko, demir, mangan, bakır ve bor analiz sonuçlarının durumu ve dağıımı Table 6. Condition and distribution of zinc, iron, manganese, copper and boron analysis results of soils used in the research

\begin{tabular}{|c|c|c|c|c|}
\hline Mikro Element & Sınır Değeri (ppm) & Değerlendirme & Toplam Örnek Sayısı & Dağılımı (\%) \\
\hline \multirow{4}{*}{$\begin{array}{c}\text { Zn } \\
\text { (Sillanpaa, 1990) }\end{array}$} & $<0.2$ & Çok az & 3 & 7.50 \\
\hline & $0.2-0.7$ & $A z$ & 18 & 45.00 \\
\hline & $0.7-2.4$ & Yeterli & 19 & 47.50 \\
\hline & $>2.4$ & Fazla & 0 & 0 \\
\hline \multirow{3}{*}{$\begin{array}{c}\text { Fe } \\
\text { (Lindsay ve Norvell, } \\
1978)\end{array}$} & $<2.5$ & $\mathrm{Az}$ & 0 & 0 \\
\hline & $2.5-4.5$ & Noksanlık görülebilir & 0 & 0 \\
\hline & $>4.5$ & İyi & 40 & 100 \\
\hline \multirow{4}{*}{$\begin{array}{c}\text { Mn } \\
\text { (Sillanpaа, 1990) }\end{array}$} & $<0.2$ & Çok az & 0 & 0 \\
\hline & $0.2-0.7$ & $A z$ & 0 & 0 \\
\hline & $0.7-5.0$ & Yeterli & 2 & 5.00 \\
\hline & $>5.0$ & Fazla & 38 & 95.00 \\
\hline \multirow{3}{*}{$\begin{array}{c}\text { Cu } \\
\text { (Lindsay ve Norvell, } \\
1978 \text { ) }\end{array}$} & $0.2-0.25$ & Orta & 3 & 7.50 \\
\hline & $0.25-1$ & Yeterli & 15 & 37.50 \\
\hline & $>1$ & Fazla & 22 & 55.00 \\
\hline \multirow{4}{*}{ (Wolf, 1971) } & $<0.5$ & $A z$ & 1 & 2.5 \\
\hline & $0.5-2.0$ & Yeterli & 35 & 87.50 \\
\hline & $2.0-5.0$ & Fazla & 4 & 10 \\
\hline & $>5.00$ & Çok fazla & - & 0 \\
\hline
\end{tabular}


Çizelge 5. Araștırmada kullanılan toprakların çinko, demir, mangan, bakır ve bor konsantrasyonları

Table 5. Zinc, iron, manganese, copper and boron concentrations of soils used in research

\begin{tabular}{|c|c|c|c|c|c|}
\hline \multirow{2}{*}{$\begin{array}{c}\text { Örnek } \\
\text { No }\end{array}$} & \multicolumn{5}{|c|}{ Toprak Mikro Elementleri (mg kg-1) } \\
\hline & $\mathrm{Zn}$ & $\mathrm{Fe}$ & $\mathrm{Mn}$ & $\mathrm{Cu}$ & $\mathrm{B}$ \\
\hline 1 & 0.3 & 35 & 26 & 0.8 & 1.4 \\
\hline 2 & 0.6 & 16 & 29 & 0.2 & 1.3 \\
\hline 3 & 1.0 & 47 & 5 & 0.1 & 1.5 \\
\hline 4 & 0.9 & 40 & 15 & 0.3 & 2.7 \\
\hline 5 & 0.7 & 34 & 18 & 0.3 & 0.8 \\
\hline 6 & 0.3 & 19 & 9 & 0.4 & 1.3 \\
\hline 7 & 2.1 & 31 & 19 & 1.4 & 1.6 \\
\hline 8 & 0.5 & 49 & 24 & 1.7 & 0.6 \\
\hline 9 & 1.2 & 52 & 27 & 0.3 & 1.3 \\
\hline 10 & 1.4 & 5 & 6 & 1.3 & 0.4 \\
\hline 11 & 0.5 & 5 & 3 & 1.2 & 0.7 \\
\hline 12 & 0.6 & 45 & 14 & 1.4 & 1.6 \\
\hline 13 & 0.4 & 15 & 8 & 0.4 & 2.1 \\
\hline 14 & 2.3 & 46 & 72 & 2.0 & 2.6 \\
\hline 15 & 0.7 & 49 & 10 & 1.6 & 1.8 \\
\hline 16 & 1.8 & 54 & 7 & 2.6 & 1.0 \\
\hline 17 & 0.8 & 62 & 13 & 2.6 & 2.5 \\
\hline 18 & 0.9 & 74 & 6 & 2.5 & 1.2 \\
\hline 19 & 1.2 & 55 & 7 & 0.8 & 1.0 \\
\hline 20 & 1.3 & 39 & 19 & 1.1 & 0.8 \\
\hline 21 & 0.9 & 15 & 14 & 0.4 & 0.5 \\
\hline 22 & 0.5 & 78 & 28 & 1.9 & 0.7 \\
\hline 23 & 1.1 & 53 & 28 & 2.5 & 0.5 \\
\hline 24 & 1.2 & 95 & 25 & 1.0 & 0.5 \\
\hline 25 & 1.0 & 50 & 8 & 0.1 & 0.7 \\
\hline 26 & 0.6 & 63 & 25 & 0.8 & 0.7 \\
\hline 27 & 0.5 & 64 & 33 & 2.5 & 1.0 \\
\hline 28 & 0.4 & 78 & 51 & 2.3 & 0.5 \\
\hline 29 & 0.1 & 26 & 32 & 1.2 & 0.8 \\
\hline 30 & 1.3 & 34 & 20 & 0.6 & 0.9 \\
\hline 31 & 0.6 & 42 & 19 & 0.8 & 1.4 \\
\hline 32 & 0.4 & 63 & 24 & 2.0 & 1.1 \\
\hline 33 & 0.1 & 18 & 12 & 0.3 & 0.6 \\
\hline 34 & 0.1 & 24 & 11 & 0.5 & 1.4 \\
\hline 35 & 0.5 & 59 & 23 & 0.4 & 1.6 \\
\hline 36 & 0.5 & 95 & 46 & 1.3 & 0.9 \\
\hline 38 & 1.2 & 30 & 8 & 4.9 & 0.7 \\
\hline 39 & 0.9 & 61 & 18 & 1.7 & 0.7 \\
\hline 40 & 0.9 & 24 & 8 & 1.5 & 1.5 \\
\hline En Düșük & 0.1 & 5 & 3 & 0.1 & 0.4 \\
\hline En Yüksek & 2.3 & 95 & 72 & 4.9 & 2.7 \\
\hline Ortalama & 0.8 & 45 & 20 & 1.3 & 1.1 \\
\hline
\end{tabular}

32 
yapılmıștır. Örneğin, Türkiye topraklarının \%49.8'inde çinko noksanlığı olduğu (Eyüpoğlu ve ark., 1998) tarafından saptanmıștır. Topraklarda Zn noksanlığı ile $\mathrm{pH}$ arasında yakın bir ilișki yer almaktadır. Toprak pH'sındaki bir birim artıșa karșın toprakta bulunan Zn'nin yarayıșılığı 100150 kat oranında azalmaktadır (Marshcener, 1995). Fındık yetiștirilen alanlarda pH'nın düșük olması nedeniyle sıkıkla kireçleme yapılmaktadır. Kireçlemeyle topraklarda noksan olan Zn noksanlığı daha da șiddetlenmektedir.

\section{SONUC VE ÖNERILER}

Ordu yöresinde fındık tarımı yapılan toprakların verimlilik durumlarının belirlenmesi ve potansiyel beslenme problemlerinin ortaya konulmasını amaçlayan bu çalıșmanın sonuçlarına göre; toprakların verimlilik düzeylerinde önemli parametrelerden makro ve mikro elementler yönünden eksiklikler olduğu tespit edilmiștir. Buna göre fındık tarımı yapılan alanlarda mutlaka toprak analizlerinin yapılıp analiz sonuçlarına göre tek besinli gübrelemeden kaçınılmalıdır. Bunun yerine içeriğinde hem makro hem de mikro elementleri barındıran gübrelerin kullanımı yaygınlaștırılmalıdır.

\section{KAYNAKLAR}

Adiloğlu A, Adiloğlu S (2005). An investigation on nutritional problems of hazelnut grown on acid soils, communication in soil science and plant analysis, 36, 22192226 .

Aydın Ș, İrget ME, Karakurt R (2000). Bartın yöresi fındık bahçelerinin beslenme durumu, Anadolu, J. Of Aarı 10 (2) $139-157$.

Bouyoucus GJ (1951). Arecalibration of hidrometer for making mechanical analysis of soils. Agron. J. 43: 434-438.

Bremner JM (1965). Total nitrogen methods of soil analysis. Part 2. Chemical and Microbiological Properties. Ed. C.A. Black. Amer. Soc. Of Agron. Inc. Pub. Agron. Series. No: 9, Madison, Wisconsin, U.S.A. $1149-1178$.

Esençayı MK, Korkmaz K (2019). Ordu topraklarının potasyum durumu ve potasyum fiksasyonunun belirlenmesi. Türk Tarım ve Doğa Bilimleri Dergisi, 6(4), 878-886.

Eyüboğlu F, Kurucu N, Talaz S(1998). Türkiye topraklarının bitkiye yarayıșlı bazı mikro elementler (Fe, Cu, Zn, Mn) bakımından genel durumu. T.C. Bașbakanlık K.H.G.M. Toprak ve Gübre Araștırma Enstitüsü Müdürlüğü. Ankara.

FAO (1990). Micronutrient. Assessment at thecountrylevel: an International study.fao soil bulletin by mikkosillanpaa. Rome.

FAO (2020). Food and agriculture data. http://Faostat. fao.org/.
Genç C., Sarıhan S (1976). Fındıkta dikimden önce bir defada verilen normal ve așırı miktarlardaki kireç ve Slam'ın fındığın verim ve kalitesine etkileri üzerinde bir araștırma. Gıda Tarım ve Hayvancılık Bakanlığı, Tarımsal Araștırma Genel Müdürlüğü. Proje No: 11 1-035--280. Giresun.

Hizalan E, Ünal H (1966). Topraklarda önemli kimyasal analizler. AÜ Ziraat Fakültesi Yayınları, 278.

Jackson ML (1958). Soil chemical analysis. Prentice Hall, Englewood Cliffs, New Jersey, USA.

Jackson ML (1962). Soil chemical analysis, Constable \& Co., Lond., p. 219

Kacar B, Katkat V (2007). Bitki Besleme Kitabı. Nobel yayınları.

Lindsay WL, Norvell WA (1978). Development of a DTPA soil test for zinc, iron, manganese and copper. Soil Science Society of America Journal, 42:421- 428.

Maas EV (1986). Salt tolerance of plants. applied agricultural research, 1:12-26.

Marschner H (1995). Mineral nutrition of higher plants. Second Edition. Academic Press, NewYork, USA

Olsen SR, Cole CV, Deah LA (1954). Estimation of available phosphorus in soil by extraction with NaHCO3. U.S. Dept. of Agr. Cic. 939. Washington, DC.USA.

Özbek N (1981). Meyve ağaçlarının gübrelenmesi. Tarım Bakanlığı Yayınları. 244- 254. Ankara.

Özkutlu F, Korkmaz K, Akgün M, Ete Ö (2016). Magnezyum gübrelemesinin fındığın (corylus avellana I.) verim ve bitki besin elementi içeriklerine etkisi. Bilim Teknoloji Dergisi, 6 (2): 48-58.

Özkutlu, F, Aydemir ÖE, Akgün M, Özcan B (2019). Ordu ilinde fındık (Corylus avellana L.) tarımı yapılan toprakların çinko (Zn) beslenme durumu ve potansiyel beslenme problemlerinin belirlenmesi. Akademik Ziraat Dergisi, 8: 131140.

Özyazıcı MA, Dengiz O, Aydoğan M, Bayraklı B, Kesim E, Urla Ö, Ünal E (2016). Orta ve Doğu Karadeniz Bölgesi tarım topraklarının temel verimlilik düzeyleri ve alansal dağııımları. Anadolu Tarım Bilimleri Dergisi, 31:136-148.

Pratt PF (1965). Potassium methods of soil analysis. (Editor: C. A. Black) part-2. Agron. Series No:9: 1010-1022 Am. Soc. of Agron., Inc. Madison, Wisconsin, USA.

Richards LA (1954). Diagnosis and improvement of saline and alkali Soils. United States Depatyment of Agriculture Handbook, 60.

Șendemirci H, Korkmaz A (2008). Orta ve Doğu Karadeniz Bölgesi topraklarının yarayıșlı Fe, Mn, Zn ve Cu bakımından durumu. Anadolu Tarım Bilimleri Dergisi, 23 (1): 39-50.

Sillanpaa M (1990). Micronutrient assessment at the country level: an international study. In: FAO Soils Bulletin. N. 63. Rome.

Tarakçığlu C, Yalçın SR, Bayrak A, Küçük M, Karabacak $\mathrm{H}$ (2003). Ordu yöresinde yetiștirilen fındık bitkisinin (Corylus avellana L.) beslenme durumunun toprak ve yaprak analizleriyle belirlenmesi. Ankara Üniversitesi Ziraat Fakültesi Tarım Bilimleri Dergisi, 9 (1):13-22. 
TUik (2020). Türkiye istatistik kurumu verileri. www.tüik. gov.tr Bitkisel Üretim İstatistikleri Veri tabanı.

Wolf $\mathrm{B}(1971)$. The determination of boron in soil extracts, plant materials, composts, manures, water and nutrient solutions. Communications in Soil Science and Plant Analysis, 2(5): 363-374. 